\title{
СУДОВА МЕДИЦИНА
}

\author{
DOI: $10.26693 / j m b s 06.02 .169$ \\ УДК 360.6:616.441-001-076 \\ Бабкіна О. П.' ${ }^{1}$ Данильченко С. І. ${ }^{2}$
}

\section{УЛЬТРАЗВУКОВА ДІАГНОСТИКА ХАРАКТЕРУ ТА ДАВНОСТІ ТРАВМИ ЖИВОТА}

\author{
'Національний медичний університет імені О. О. Богомольця, \\ Київ, Україна \\ гчорноморський національний медичний університет імені Петра Могили, \\ Миколаїв, Україна
}

hpbsme@gmail.com

Метою даної роботи було вивчення комплексу змін ультразвукових показників травмованих тканин печінки, селезінки, підшлункової залози при механічній травмі та їх залежність від характеру та давності травмування.

Матеріал та методи дослідження. Були проведені ультразвукові дослідження у 60 травмованих пацієнтів (41 чоловічої та 19 жіночої статі) віком від 20 до 60 років в динаміці на 1, 2, 3, 4 та 5 добу після отримання травми. Застосовували прокольне, поперечне та косе сканування з усіх можливих доступів згідно протоколу ультразвукового сканування органів черевної порожнини та заочеревинного простору послідовно в В-режимі. Досліджували стан печінки, підшлункової залози, селезінки, нирок.

Результати. В ході проведених досліджень продемонстрована висока кількість ушкоджень органів черевної порожнини та за очеревинного простору, доведено, що ізольовані ушкодження печінки спостерігалися 32\%, в 68\% травма печінки була сукупною з ушкодженнями інших органів черевної порожнини. Ізольовані ушкодження підшлункової залози спостерігали в 10\%, в інших 90\% травма підшлункової залози була сукупною з ушкодженнями печінки, жовчного міхура та позапечінкових жовчних протоків, селезінки, кишечнику. Ізольовані ушкодження селезінки спостерігалися у пацієнтів в 31\%, в інших випадках травма селезінки була сукупною з ушкодженнями інших органів черевної порожнини. Ізольовані ушкодження нирок спостерігали практично 15\%. В 85\% випадках ушкодження нирок виявлялися у сполученні з травмами інших паренхіматозних органів. Продемонстровано, що в області травмованих тканин печінки, підшлункової залози, селезінки, нирок при тупій травмі живота у осіб з відсутністю ознак алкогольної інтоксикації спостерігаються закономірні ультразвукові зміни, які знаходяться в прямій залежності від часу, що минув з моменту заподіяння ушкоджень.

Висновки. Доведено, для визначення часу заподіяння ушкоджень використання в комплексі змін в паренхіматозних органах, виявлених при ультразвукових дослідженнях, як у випадках ізольованої травми органу, так і у випадках сполученої травми органів черевної порожнини та за очеревинного простору, є доцільним, тому що дає змогу підвищити об'єктивність результатів встановлення давності заподіяння травми.

Ключові слова: ультразвукові дослідження, діагностика, тупа травма, печінка, селезінка, підшлункова залоза, нирки, давність ушкодження.

Дане дослідження є ініціативним.

Вступ. Актуальність проблеми більш якісного вирішення питань встановлення характеру, механізму та давності виникнення травми живота обумовлює велику кількість проведених досліджень з широким застосуванням сучасних лабораторних методів досліджень, спрямованих на об'єктивізацію експертних критеріїв. Важливість досліджуваної проблеми пов'язана також з працездатним віком загиблих від механічної травми. Серед різновидів травми живота спостерігається доволі високий рівень летальності: у випадках ізольованих ушкоджень живота від 5 до 10\% і 20-30\% при множинних ушкодженнях [1-8]. За даними науковців ушкодження травма органів черевної порожнини та заочеревинного простору складає 5-10\%, з яких до 56\% припадає на печінку, 24-42\% - на тонку кишку, заочеревинна гематома зустрічається в 5-50\% спостережень [9-14]. Кількість ушкоджень підшлункової залози в загальній структурі механічної травми паренхіматозних органів черевної порожнини за різними даними складає від 1,5 до 9\% та характеризується високою летальністю за 
різними даними від 12\% до 42\% внаслідок відсутності клінічних симптомів, тому $є$ труднощі в діагностиці. Дані в літературних джерелах стосовно кількості травм селезінки різняться і, в середньому, автори зазначають, що ушкодження селезінки спостерігаються від 15\% до 33\% випадків. Ушкодження нирок зустрічаються за даними літератури від 6\% до 18\% випадків та в 60\% випадків поєднувалися з травмою інших органів черевної порожнини та заочеревинного простору [15-21]. За останній час спостерігається також збільшення кількості закритих пошкоджень живота, які супроводжуються порушенням цілісності органів [22-28].

Вивченню питань характеру, механізму та часу виникнення ушкоджень органів черевної порожнини у живих осіб приділено багато уваги. За допомогою великої кількості різноманітних досліджень розкриті нові закономірності патологічних змін в залежності від часу, що минув після травми. [29-34]. При травмі живота одним з доказових та інформативних методів дослідження $є$ ультразвукова діагностика, за допомогою якої $€$ можливим проведення послідовного та ретельного обстеження внутрішніх органів, зокрема печінки, селезінки, підшлункової залози, нирок, як з метою виявлення наявності та характеру ушкоджень, так і з метою діагностики давності їх виникнення.

Метою даної роботи було вивчення комплексу змін ультразвукових показників травмованих тканин печінки, селезінки, підшлункової залози при механічній травмі та їх залежність від характеру та давності травмування.

Матеріал та методи дослідження. Були проведені ультразвукові дослідження у 60 травмованих пацієнтів (41 чоловічої та 19 жіночої статі) віком від 20 до 60 років при зверненні в медичні заклади, а також в динаміці на 1, 2, 3, 4 та 5 добу після отримання пацієнтами травми. Ультразвукову діагностику з метою виявлення патологічних змін органів і тканин проводили за допомогою ультразвуку частотою від 0,5 до 1,5 млн коливань на апаратах Sonoace 8000 (Південна Корея), Sonosite Titan (США) з використанням низькочастотних датчиків, які дозволяли проводити дослідження на великій глибині. Застосовували прокольне, поперечне та косе сканування з усіх можливих доступів згідно протоколу ультразвукового сканування органів черевної порожнини та заочеревинного простору послідовно в В-режимі. досліджували стан печінки, підшлункової залози, селезінки, нирок.

Робота була проведена відповідно до вимог «Інструкції про проведення судово-медичної експертизи» (наказ МО3 України №6 від 17.01.1995), відповідно до вимог і норм, типовим положенням 3 питань етики МОЗ України № 690 від 23.09.2009 р.

\section{Результати дослідження та їх обговорен-} ня. В ході проведених досліджень ізольовані ушкодження печінки спостерігалися у 19 пацієнтів (32\%), в 41 випадках (68\%) травма печінки була сукупною з ушкодженнями інших органів черевної порожнини. Ізольовані ушкодження підшлункової залози спостерігали у 6 пацієнтів (10\%), з яких 4 чоловічої та 2 жіночої статі, в інших 54 постраждалих $(90 \%)$ була сукупною з ушкодженнями печінки, жовчного міхура та позапечінкових жовчних протоків, селезінки, кишечнику. Ізольовані ушкодження селезінки спостерігалися у 18 пацієнтів (31\%), в 42 випадках (69\%) травма селезінки була сукупною 3 ушкодженнями інших органів черевної порожнини. Ізольовані ушкодження нирок спостерігали у 9 пацієнтів, що склало практично 15\%. В 85\% випадках (51 постраждалий) ушкодження нирок виявлялися у сполученні з травмами інших паренхіматозних органів.

Під час проведення ультразвукових досліджень при підозрі на травмування печінки оцінювали наявність, локалізацію та кількість вільної рідини в черевній порожнині, визначали наявність або відсутність ушкоджень близько розташованих органів та тканин. Відсутність вільної рідини у черевній порожнині мінімізувала вірогідність розривів печінки та її судинно-секреторного апарату. При ізольованій травмі печінки візуалізація її практично не страждала. В випадках, коли ушкодження печінки спостерігалися в сукупності з ушкодженнями порожнистих органів та підшлункової залози, візуалізація печінки значно погіршувалася через наявність газів та рідини у черевній порожнині. У всіх пацієнтів розташування печінки було типове, випадків відриву органу від зв'язкового апарату не було. Визначалися дві долі з опуклою діафрагмальною та плоскою вісцеральною поверхнями. При наявності вільної рідини у 9 постраждалих навкруги печінки капсула ії̈ не візуалізувалася. При ушкодженнях паренхіми в периферійних відділах органу контури печінки були нерівні, розмиті. Ехогенність, однорідність структури та звукопровідність печінки залежали від початкового стану організму та характеру травми. При наявності ультразвукових ознак ушкодження печінки вільна рідина була виявлена в практично 37\% випадків. При огляді хворого в горизонтальному положенні найбільш часто вільну рідину виявляли в пологих місцях черевної порожнини, правому боковому каналі та порожнині малого тазу. Встановлено, що кількість рідини, яку визначали за ультразвуковими показниками, у всіх випадках, була меншою, ніж при виявленні інтраоперативно. В середньому, 1 мм ультразвукової смужки рідинного скупчення в проекції бокового каналу відповідав 50 мл рідини, яка виявлялася при операції. Кількість рідини 
в невеликих міжпетелькових скупченнях оцінювати було ще важче. В порожнині малого тазу 100 мл рідини, яка визначалася при УЗД відповідала 200300 мл рідини інтраопераційно. У 9 постраждалих при УЗД вільна рідина у черевній порожнині не була знайдена, хоча під час операційного втручання було виявлено від 20 до 200 мл рідини.

Головними ультразвуковими ознаками ушкодження печінки були розриви паренхіми з утворюванням внутрішньо-паренхіматозних або під капсульних гематом. Взагалі, практично для всіх постраждалих були характерними збільшення розмірів печінки (частіше через збільшення ушкодженої долі), неоднорідність структури, розмитість контурів та їх переривчастість, наявність гіпо- та анехогенних ділянок (гематом) на фоні непошкодженої паренхіми. Внутрішньо-паренхіматозні гематоми виявлені у 42 постраждалих (70\%), підкапсульні - у 18 постраждалих (30\%).

За кількістю ушкоджень печінки розрізняли поодинокі та множинні. Поодинокі гематоми виявлені в 78\% спостережень (48 постраждалих), множинні в 20\% (12 осіб). Максимальна кількість виявлених гематом - $2 \%$ (у 1 хворого).

Виявлені наступні особливості локалізації гематом: в правій долі печінки у 53 постраждалого (67\%), в лівій - у 7 постраждалих (11\%), одночасне ураження правої та лівої доль склало 14 травмованих осіб (22\%).

В перші 6 годин гематоми характеризувалися ділянками зниженої ехогенності з розмитими нерівними контурами (стадія травматичної інфрільтрації). Через 12-24 години спостерігали ознаки формування рідинного компоненту на місці гіпо- та анехогенних включень у паренхімі. В цей період підкапсульна гематома печінки характеризувалася наступними ультразвуковими ознаками: розташування в периферійних відділах печінки, безпосередньо під капсулою; одно або багатокамерним об'ємним утворенням; округлою або серпоподібною формою; внутрішній вміст анехогенного або гіпоехогенного характеру, однорідний або неоднорідний; контури нечіткі, нерівні (межа нечітка, нерівна). Внутрішньо-паренхіматозні гематоми спостерігали у вигляді утворень округлої форми з однорідною анехогенною або гіпоехогенною структурою, з розташуванням у центральних відділах печінки. У перші 6 годин контури гематом були нечіткими, розмитими, навколо них у 45 постраждалих $(75 \%)$ спостерігали гіперехогенний обідок. В режимі кольорового допплеровського картування судинний рисунок печінки в проекції гематоми був відсутній, по периферії - архітектоніка його змінювалася. Через 12-24 години з моменту травмування внутрішньо-паренхіматозні гематоми приймали правильну, частіше округлу форму, межі їх ставали більш чіткими (рис. 1).

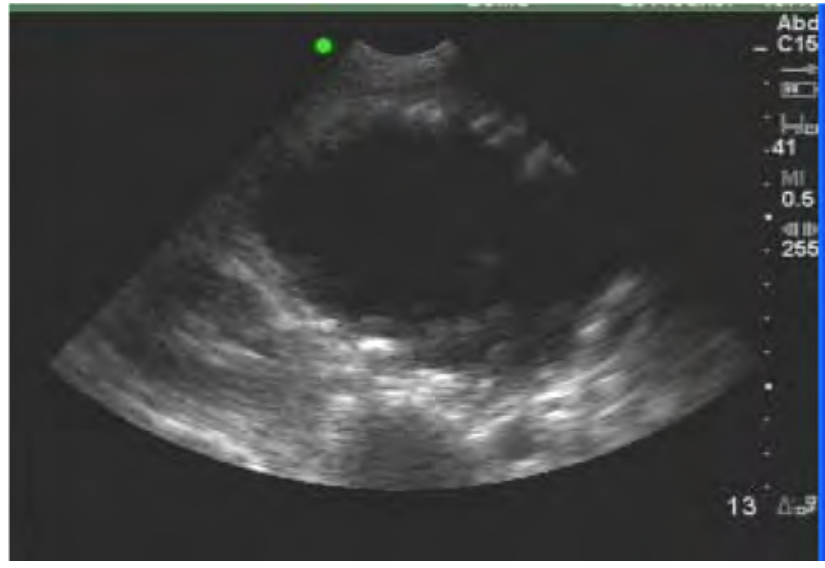

Рис. 1. Формування підкапсульної гематоми печінки жінки, 35 років, через 22 години після травми. В-режим

3 2-ї по 7 добу ультразвукова картина під- та внутрішньо-підкапсульних гематом стає відносно стабільною. На фоні гіпо- або анехогенних утворень $з$ ефектом дистального псевдо посилення, були виявлені ділянки неоднорідної або зернистої внутрішньої структури. В цей період гематоми збільшувалися до своїх максимальних розмірів. У 31 випадку (68\%) спостерігали стабільний перебіг гематом печінки. До кінця першої неділі анехогенна структура гематом приймала зернисту структуру за рахунок появи ділянкових структур середньої або високої ехогенності. Гіперехогенна зона навкруги гематом зникала. Гемоліз еритроцитів в середині гематом характеризувався появою в даний час великої кількості анехогенних включень. У 12 випадках, коли кровотеча в порожнину гематоми продовжувалася, структура гематоми змінювалася: збільшувалися розміри не менш ніж в 1,5 рази, з'являлися анехогенні структури на фоні виниклої гіперехогенної крові. Навкруги гематоми знову спостерігається обідок, в більшості випадків за рахунок просочування геморагічної рідини в навколишні тканини печінки. Такі гематоми розцінювалися як нестабільні (рис. 2).

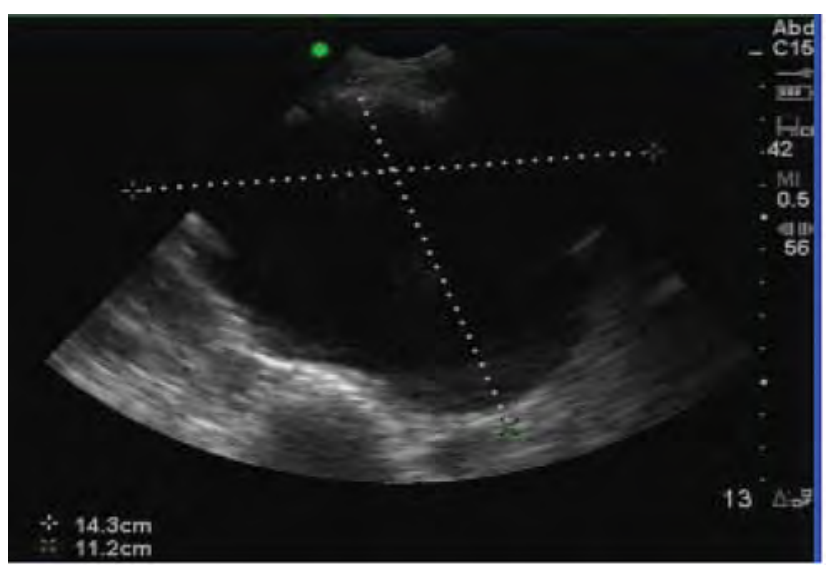

Рис. 2. Збільшення розмірів та зміна структури нестабільної гематоми печінки чоловіка, 38 років, на 5 добу після травми. В-режим 
Через 7 та більше діб після травми гематоми не збільшувались у розмірах. Вони візуалізувались у вигляді поодиноких або множинних анехогенних утворювань округлої форми з чіткими рівними контурами, однорідних або неоднорідних, але за стабільною внутрішньою структурою.

Ізольовані ушкодження підшлункової залози спостерігали у 6 пацієнтів (10\%), з яких 4 чоловічої та 2 жіночої статі, в інших 54 постраждалих (90\%) була сукупною з ушкодженнями печінки, жовчного міхура та позапечінкових жовчних протоків, селезінки, кишечнику. За отриманими даними при встановленні даного виду травми допомагає добре зібраний анамнез, знання механізму травми, лабораторні дослідження крові та сечі (визначення збільшення в крові вмісту трипсину, амілази, ліпази, тощо), проведення лапароскопії черевної порожнини та заочеревинного простору, УЗД внутрішніх органів черевної порожнини. Клінічна та ультразвукова діагностика травм підшлункової залози є достатньо складною у всіх випадках механічної травми. Ультразвукове дослідження ускладнювалося наявністю гіперпневматозу кишечнику при розвитку динамічної непрохідності кишок та розлитого перитоніту.

В перші 6 годин спостерігали відсутність чітких контурів залози, їх переривчатість, збільшення розмірів залози у 1,5-2 рази, зміна характеру ехогенності за рахунок появи гіпоехогенних ділянок різного розміру. При повному розчавлені залози в її проекції визначали безструктурну масу з наявністю перипанкреатичної рідинної інфільтрації. Перипанкреатична рідина, яку спостерігали в 8 випадках в перші години після травми, мала вигляд гіпо- та анехогенних утворень в проекції сальникової сумки. У даних постраждалих підшлункова залоза не мала чітких меж та форми, в заочеревинній клітковині формувався більш чи менш великий інфільтрат (рис. 3, 4).

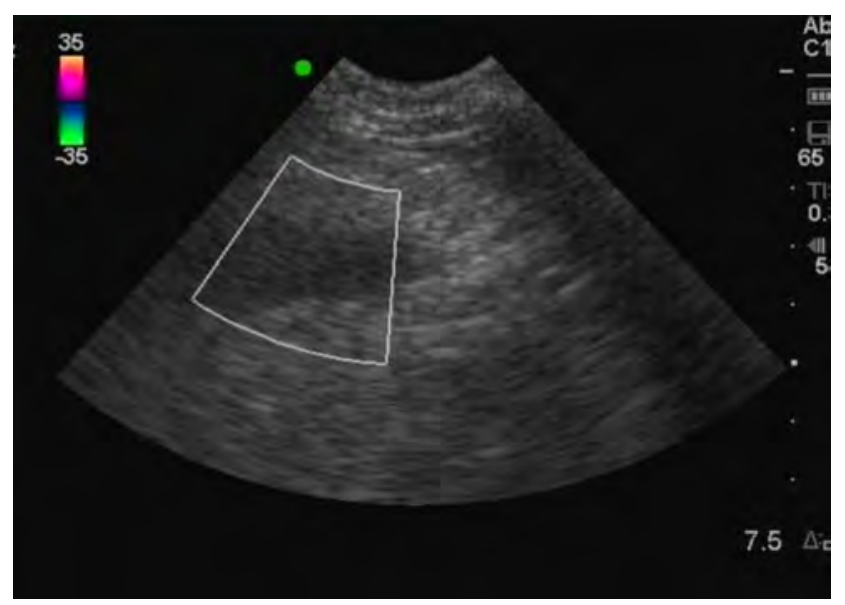

Рис. 3. Гостре рідинне скупчення в проекції головки підшлункової залози жінки, 26 років, в перші 6 годин після травми. В-режим

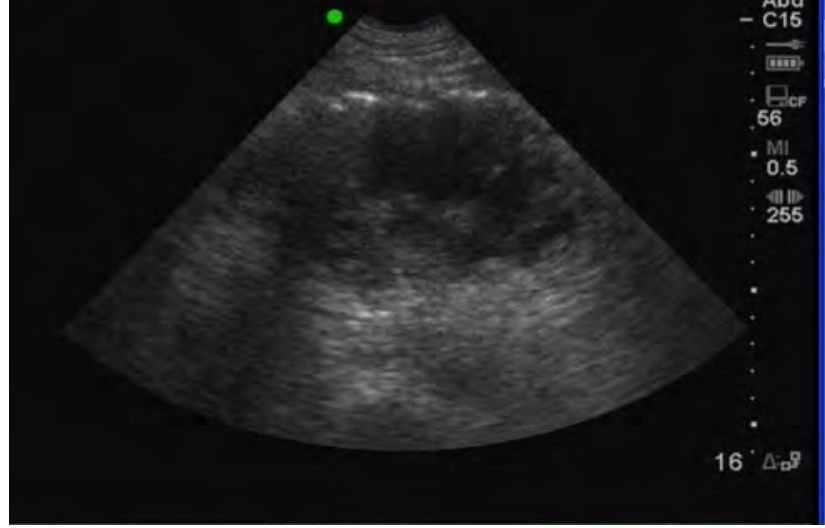

Рис. 4. Перипанкреатичний інфрільтрат чоловіка, 22 років, в перші 6 годин після травми. В-режим

Через 18-24 години після травми, ультразвукові критерії ставали більш чіткими на фоні посттравматичного панкреатиту, який починав утворюватися в даний час. Скупчення рідини в сальниковій сумці розцінювалося, як один з достовірних критеріїв ушкодження підшлункової залози (рис. 5, 6).

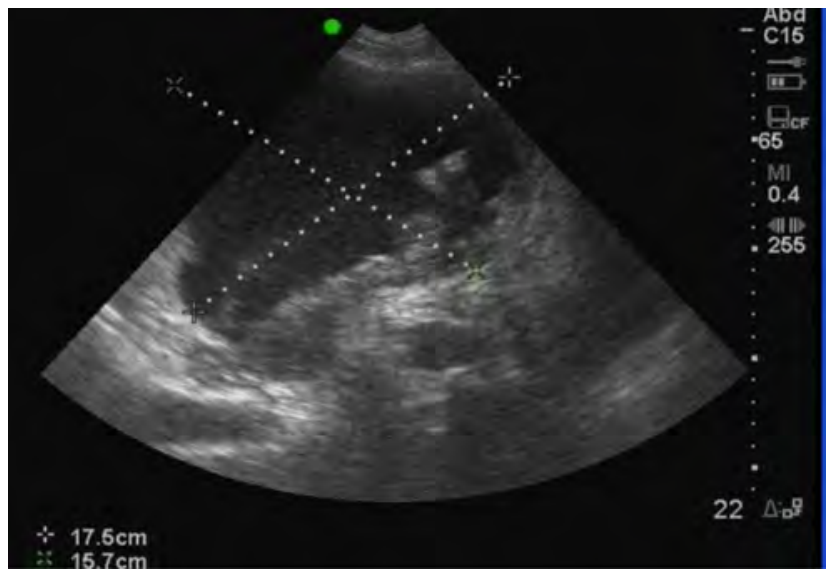

Рис. 5. Скупчення рідини в сальниковій сумці в проекції хвоста підшлункової залози чоловіка, 48 років, через 18 годин після травми. В-режим

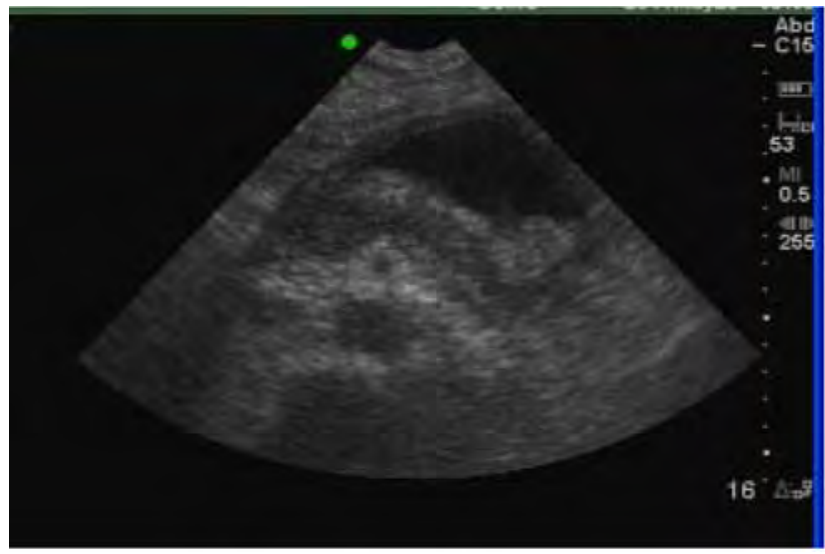

Рис. 6. Скупчення рідини в сальниковій сумці чоловіка, 48 років, через 3 доби після травми. В-режим

3 2-ї по 7 добу у 11 хворих прогресували явища інфільтративного панкреатиту. У випадках розвитку неінфільтративного панкреонекрозу 
у пацієнтів спостерігали картину псевдокист підшлункової залози у вигляді поодиноких або множинних утворень округлої або овальної форми, які містили рідину з дистальним псевдо посиленням (рис. 7).

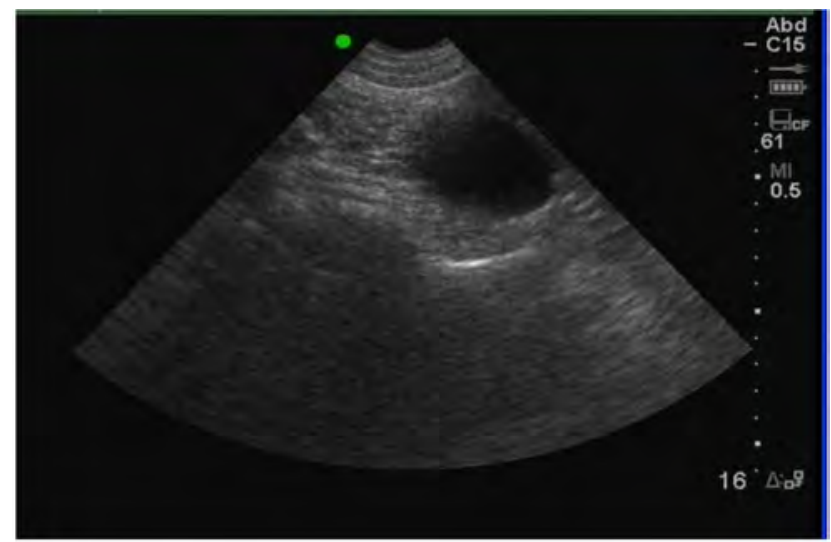

Рис. 7. Формування псевдокисти в проекції хвоста підшлункової залози чоловіка, 56 років, на 4 добу після травми. В-режим

В режимі кольорового допплерівського картування такі рідинні скупчення були у вигляді поодиноких або множинних утворень округлої або овальної форми, інколи з потовщеними стінками (рис. 8).

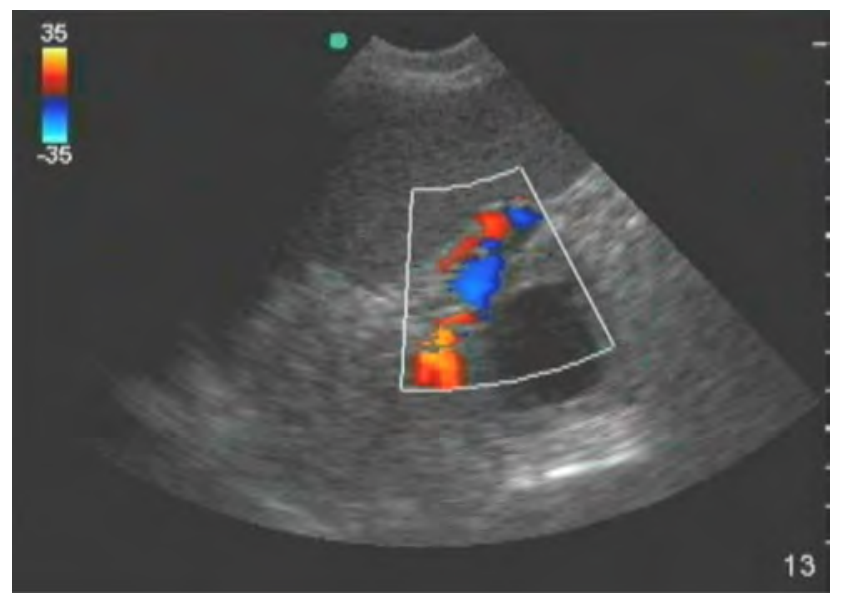

Рис. 8. Формування псевдокисти в проекції головки підшлункової залози жінки, 26 років, на 5 добу після травми. Режим кольорового допплерівського картування

У випадках, коли спостерігали розвиток панкреонекрозу, ультразвукова картина рідинних скупчень змінювалася за рахунок потовщення стінок. При розвитку інфікованого панкреонекрозу ультразвукова картина рідинних скупчень змінювалась: стінки потовщувались, в середньому,

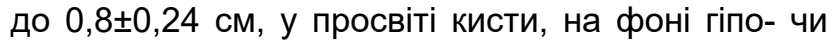
анехогенного вмісту, візуалізувались гіперехогенні маси, які займали до 1/2 просвіту. Гіперехогенні включення на підставі клінічної картини були розцінені як секвестри підшлункової залози в результаті тяжкого панкреонекрозу (рис. 9, 10).

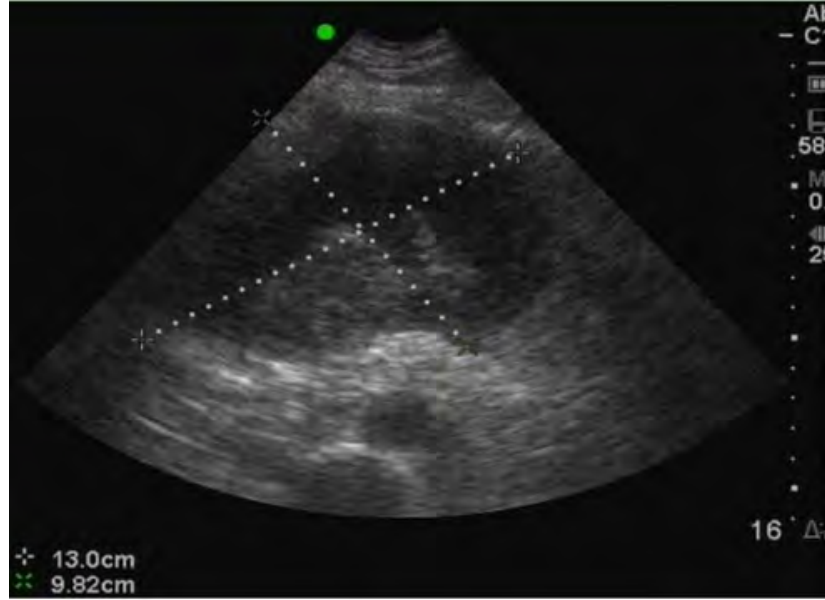

Рис. 9. Секвестрація у порожнині псевдокисти хвоста підшлункової залози чоловіка, 38 років, на 7 добу після травми. В-режим

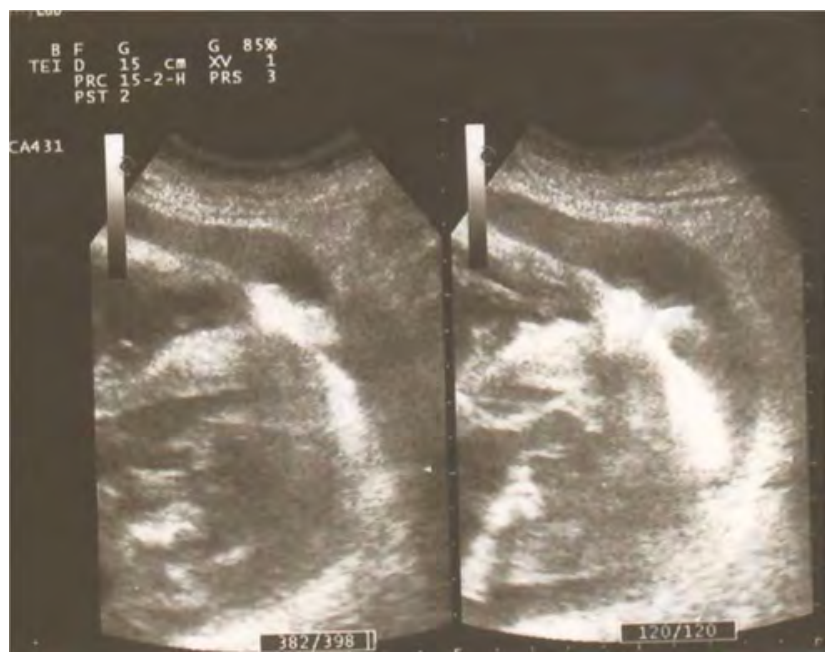

Рис. 10. Інфільтрування псевдокисти в проекції хвоста підшлункової залози, чоловіка, 40 років, на 9 добу після травми. В-режим

Після 7 доби можливий повний самочинний лізис псевдокист невеликих розмірів або розвиток нагноєння. Через 2-3 неділі після травми в 4 випадках спостерігали кровотечу з ерозивних судин у порожнині псевдокисти або парапанкреатичного інфільтрату.

Ізольовані ушкодження селезінки спостерігалися у 19 пацієнтів (31\%), в 41 випадках (69\%) травма селезінки була сукупною з ушкодженнями інших органів черевної порожнини. При ультразвуковому дослідженні вважали за головні ознаки ушкодження селезінки виявлення неоднорідності паренхіми та наявності анехогенної структури, а також наявність вільної рідини в черевній порожнині. В 41 випадку (69\%) спостерігали нечіткість та нерівність контурів селезінки, а також збільшення її розмірів. У постраждалих з ушкодженнями селезінки в перші 6 годин за наявності гематоми, спостерігали відсутність чітких контурів органу, зміну характеру її ехогенності за рахунок появи гіперехогенних ділянок різного розміру (рис. 11). 


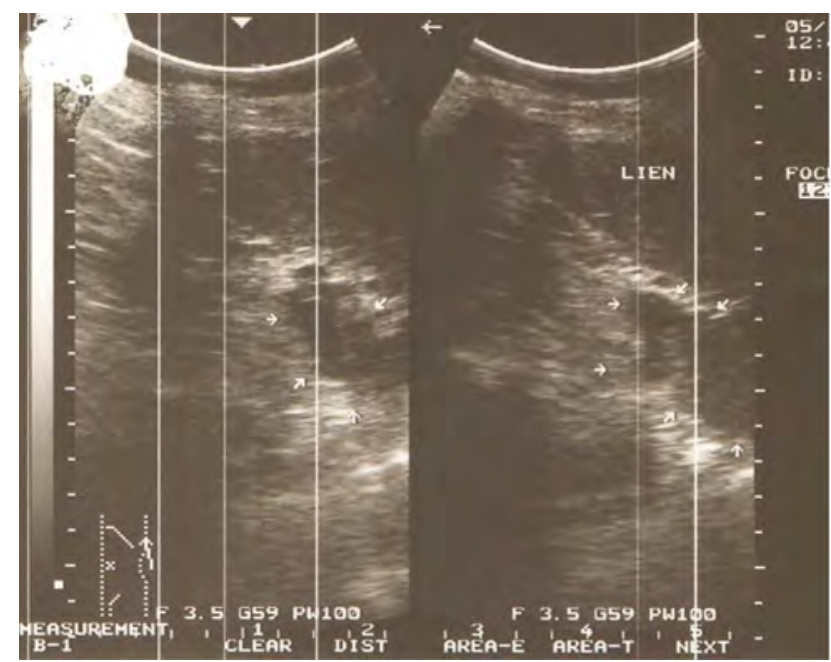

Рис. 11. Гостре рідинне скупчення в проекції селезінки чоловіка, 54 років, в перші 6 годин після травми. В-режим

Протягом наступних 12-24 годин у пацієнтів спостерігали неоднорідну гіпоехогенну внутрішню структуру гематом; наявність гіпоехогенних включень в паренхімі селезінки (рис. 12, 13).

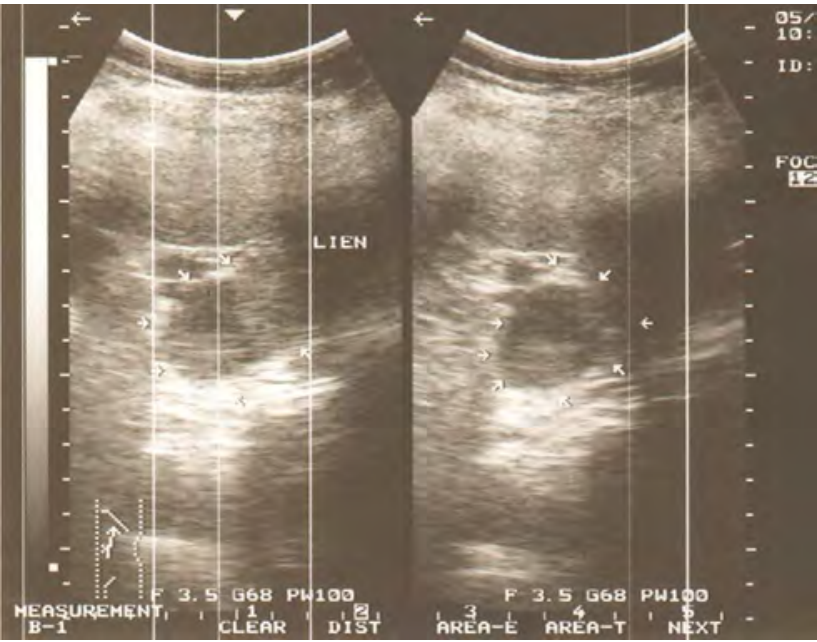

Рис. 12. Рідинне скупчення в проекції нижнього полюсу селезінки жінки, 20 років, через 16 годин після травми. В-режим

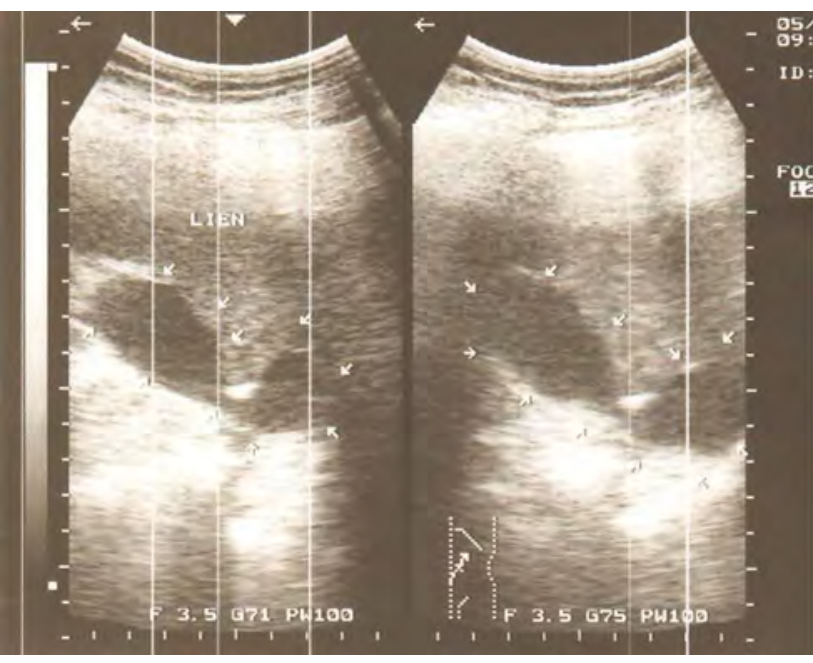

Рис. 13. Рідинне скупчення в проекції нижнього полюсу селезінки чоловіка,48 років через 22 години після травми. В-режим
32 по 7 добу ультразвукова картина гематом стає стабільною, контури гематом відносно чіткі, гематоми збільшувались у розмірах, їхня внутрішня ехогенна структура могла бути як однорідною, так і неоднорідною (рис. 14, 15).

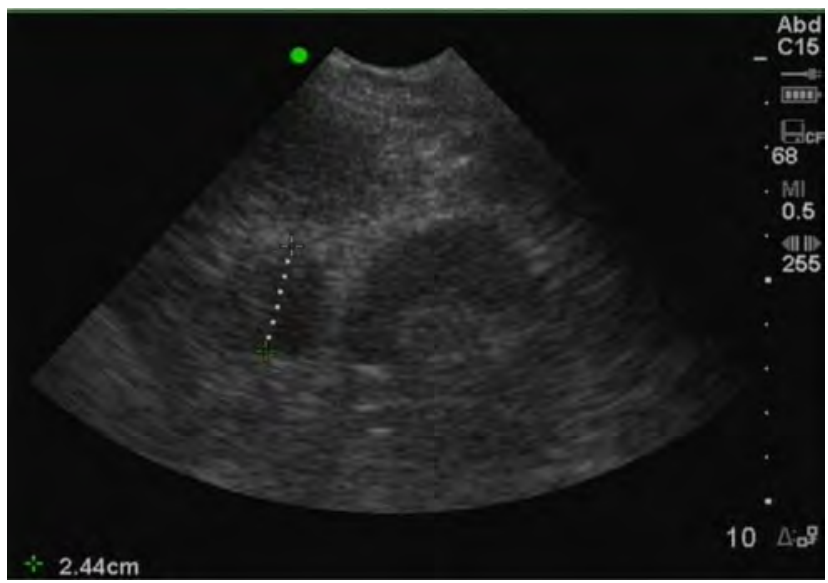

Рис. 14. Утворення округлої форми з нечіткими контурами, неоднорідним внутрішнім вмістом селезінки чоловіка, 39 років, на 3 добу після травми. В-режим

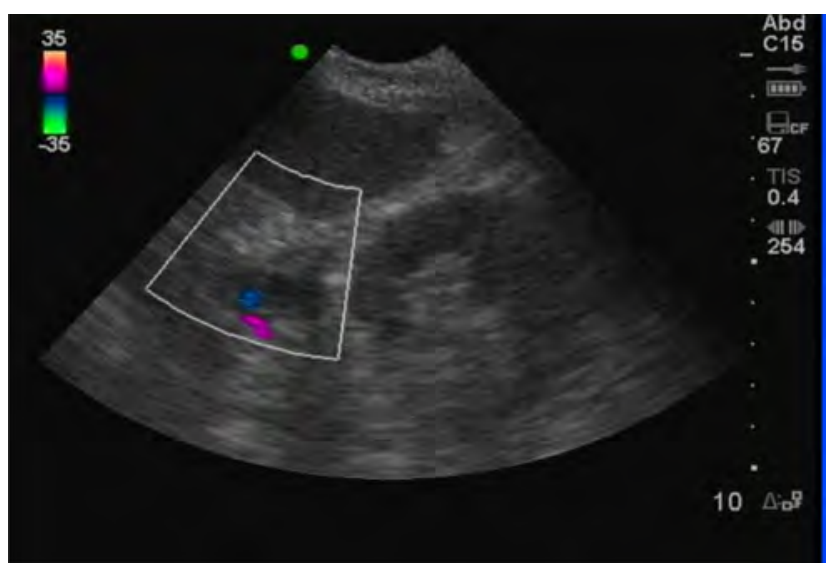

Рис. 15. Рідинне утворення з нечіткими контурами селезінки чоловіка, 39 років, на 4 добу після травми.

Режим кольорового допплерівського картування

Після 7 доби з моменту травми гематоми у розмірах не збільшувались. Вони візуалізувались у вигляді поодиноких або множинних анехогенних утворювань овальної форми з чіткими рівними контурами, однорідної або неоднорідної структури, але зі стабільною внутрішньою структурою.

В 4\% спостережень з загальної кількості постраждалих з ушкодженнями селезінки були виявлені розриви селезінки. При розчавлені селезінки (2\%) візуалізували відсутність нормальної структури селезінки, деформацію контурів і форми органу.

Спостерігались ізольовані ушкодження нирок у 9 пацієнтів, що склало практично 15\%. В 85\% випадках (51 постраждалий) ушкодження нирок виявлялися у сполученні з травмами інших паренхіматозних органів. Травмування правої нирки спостерігали в 59\% постраждалих (35 осіб), лівої - 
41\% (25 осіб). Характерними ознаками гематоми нирок вважали: збільшення їх розмірів, неоднорідність структури, яка виявлялась у підвищенні ехогенності паренхіми, розмитість контурів та їхня переривчатість. В перші 6 годин після травмування гематоми характеризувалися наявністю ділянок підвищеної ехогенності з розмитими, нерівними контурами (стадія травматичної інфрільтрації), що показано на рисунках 16, 17.

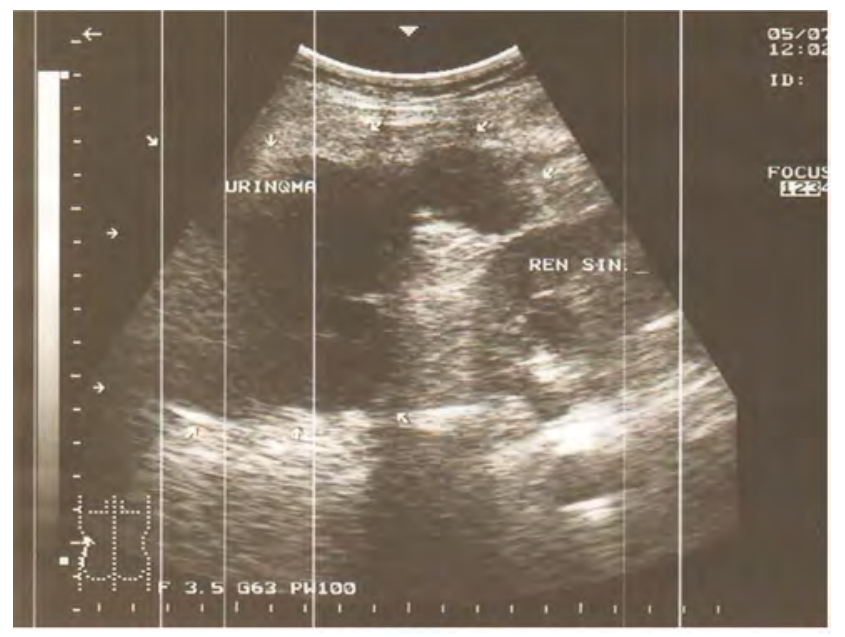

Рис. 16. Гостре рідинне скупчення в паранефральній клітковині зліва у чоловіка, 30 років, в перші 6 годин після травми. В-режим

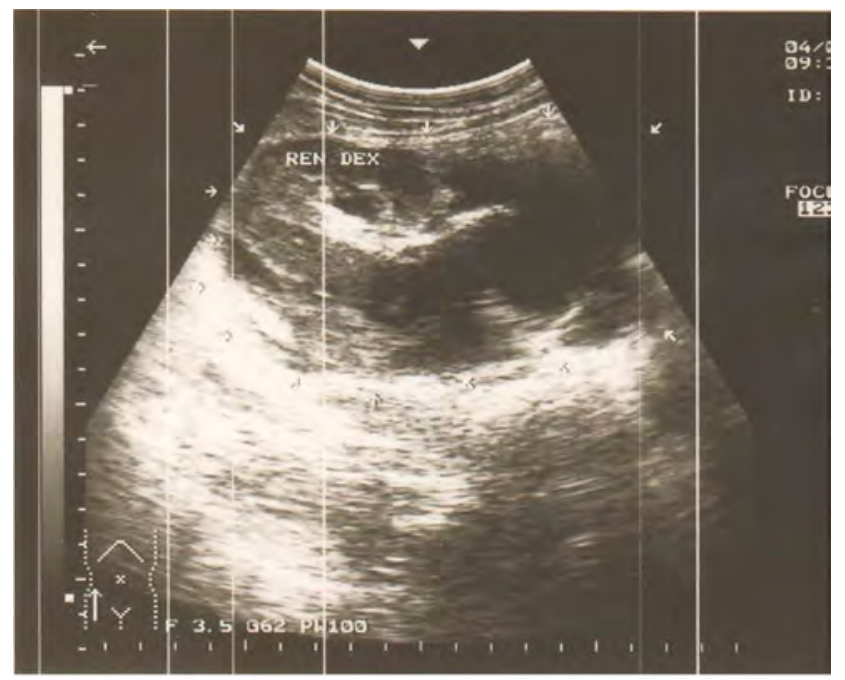

Рис. 17. Підкапсулярна гематома в проекції нижнього полюсу лівої нирки у жінки, 29 років, в перші 6 годин після травми. В-режим

Протягом наступних 12-24 годин гематоми візуалізувалися як гіпоехогені включення в паренхімі нирок з неоднорідною структурою, контури їх ставали більш чіткими (рис. 18, 19).

В наступні 3-4 доби гематоми збільшувались до своїх максимальних розмірів, візуалізувалися як рідинні утворення з нечіткими контурами гіпоехогенної однорідної або неоднорідної структури (рис. 20, 21).

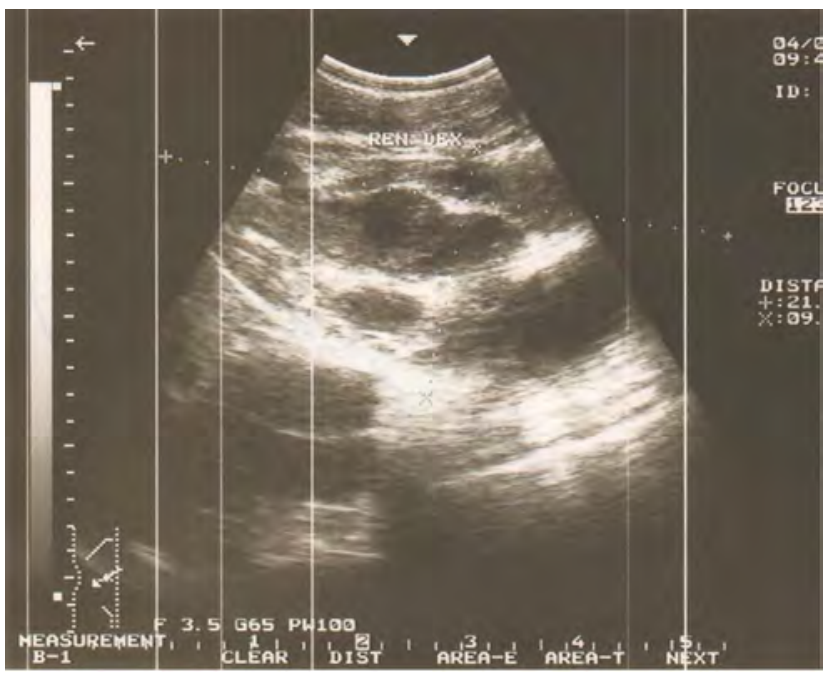

Рис. 18. Підкапсулярна гематома в проекції нижнього полюсу лівої нирки у жінки, 60 років, через 12 годин після травми. В-режим

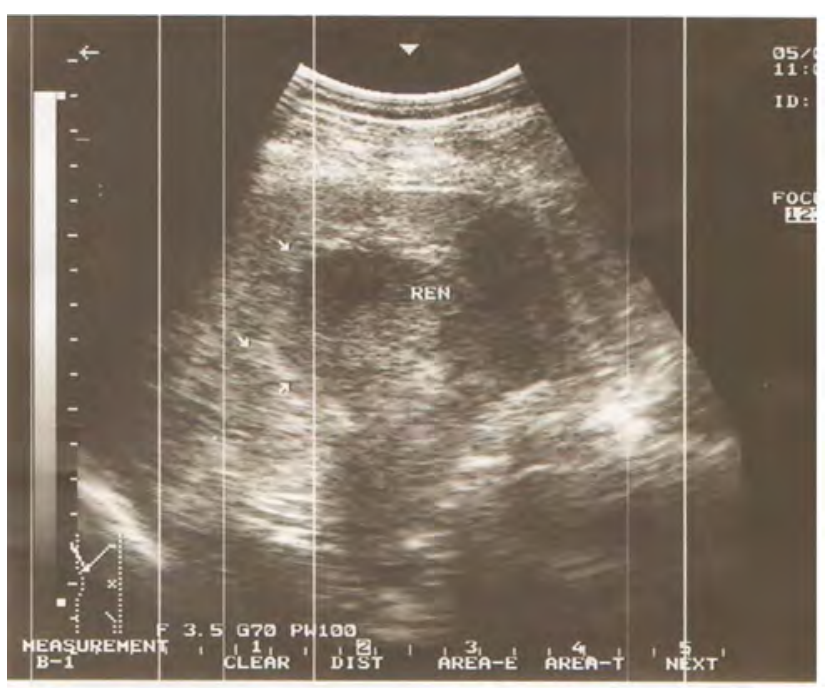

Рис. 19. Підкапсулярна гематома в проекції верхнього полюсу правої нирки у жінки, 37 років, через 24 години після травми. В-режим

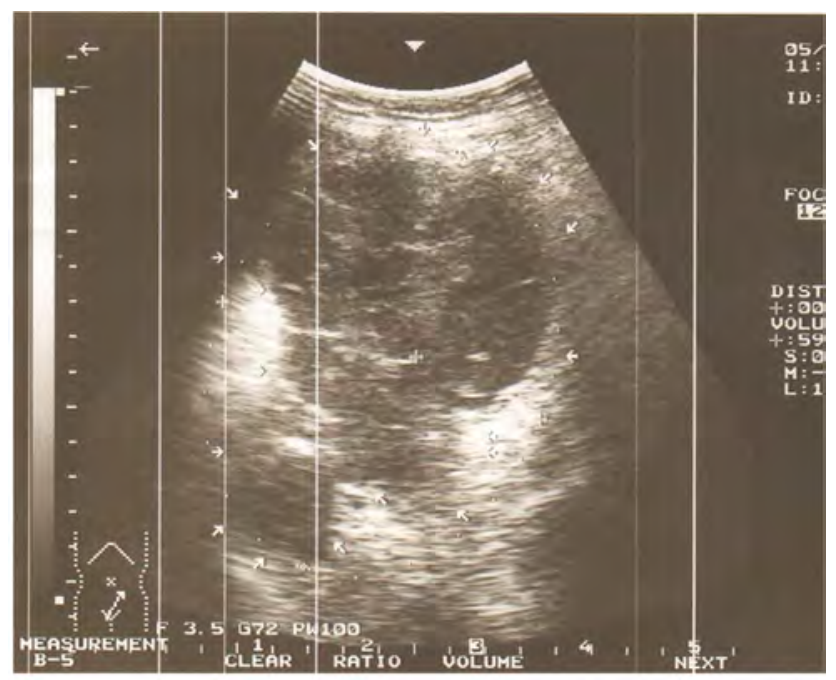

Рис. 20. Гематома в заочеревинній клітковині лівої клубової ділянки чоловіка, 40 років, через 3 доби після травми. В-режим 


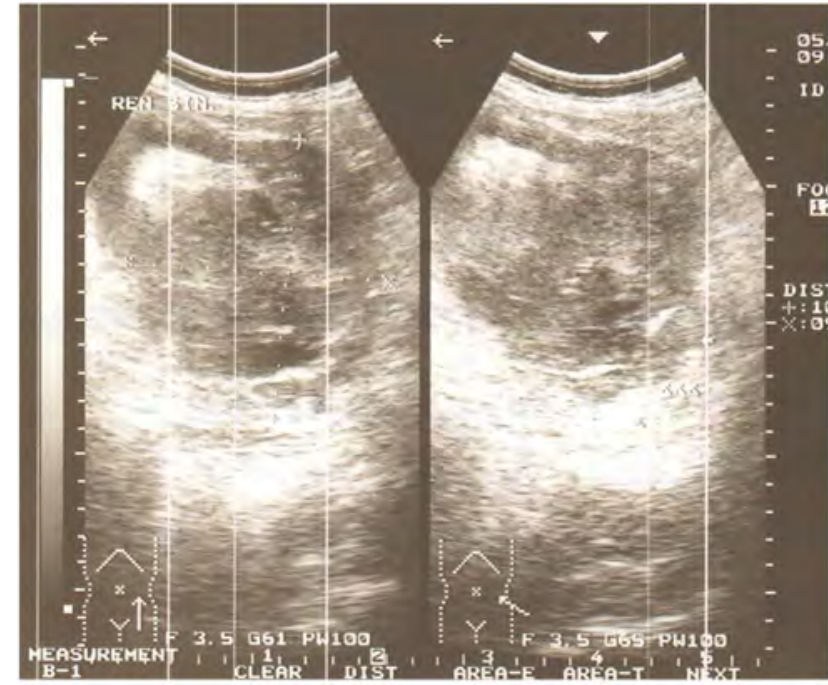

Рис. 21. Підкапсульна гематома в проекції нижнього полюсу лівої нирки чоловіка, 22 років, через 5 діб після травми. В-режим

Через 7 діб гематоми не збільшувались в розмірах, контури їх були чіткими, рівними, гіпоехогенність гематоми зменшувалась, ушкоджені тканини відновлювались.

Ультразвуковий метод дослідження застосовується для виявлення гематом (внутрішньопаренхіматозних, субкапсулярних), порушення цілісності вищезазначених органів (розривів), наявності вільної рідини в черевній порожнині, гематом м'яких тканин передньої черевної стінки, тощо [35-40]. Проведення даного методу дослідження в динаміці, через деякі часові інтервали, допомагає спостерігати закономірні зміни розвитку вищезазначених ушкоджень та динаміку їх загоєння при травмі живота. Своєчасне виявлення ушкоджень, особливо протягом першої доби з моменту травмування, завдяки якому встановлюється характер, та давність травми, значно поліпшує вибір методів діагностики та лікування пацієнтів та зменшує рівень летальності.

Таким чином, в результаті проведених досліджень виявлені закономірні зміни ультразвукових показників паренхіматозних органів черевної порожнини та заочеревинного простору в залежності від давності настання травми. Головними ультразвуковими ознаками ушкоджень печінки, підшлункової залози, селезінки та нирок вважали: збільшення розмірів органів, неоднорідність структури, розмитість контурів та їх переривчастість, наявність ан- та гіпоехогенних ділянок (гематом) на фоні непошкоджених тканин, наявність вільної рідини в черевній порожнині.

\section{Висновки}

1. Запропонований комплексний підхід, що ґрунтується на визначенні ультразвукових показників паренхіматозних органів черевної порожнини та заочеревинного простору, оптимізує точність та вірогідність вирішення питань щодо давності заподіяння травми.
2. В ході проведених досліджень ізольовані ушкодження печінки спостерігалися в 32\%, 68\% травма печінки була сукупною з ушкодженнями інших органів черевної порожнини. Головними ультразвуковими ознаками ушкодження печінки слід вважати розриви паренхіми з утворенням внутрішньо-паренхіматозних або підкапсульних гематом, для яких характерними ультразвуковими критеріями $є$ збільшення розмірів печінки (частіше внаслідок збільшення ушкодженої частки), неоднорідність структури, розмитість контурів та їх переривчастість, наявність гіпо- та анехогенних ділянок (гематом) на фоні непошкодженої паренхіми. Внутрішньо-паренхіматозні гематоми виявлені у 70\% спостережень, підкапсульні у 30\%.

3. Встановлено, що клінічна та ультразвукова діагностика у всіх випадках механічної травми з ушкодженням підшлункової залози $€$ достатньо складною. Ізольовані ушкодження підшлункової залози спостерігалися в $10 \%$ травмованих осіб, в інших випадках травма підшлункової залози була поєднана з ушкодженнями печінки та позапечінкових жовчних протоків, селезінки, кишечнику. Характерними ультразвуковими критеріями ушкоджень підшлункової залози в першу добу є відсутність чітких контурів залози, їх переривчастість, збільшення розмірів залози, наявність гіпоехогенних ділянок різного розміру. У випадках повного розчавлення залози в ії проекції визначається безструктурна маса з перипанкреотичною рідинною інфільтрацією, яка має вигляд гіпо- та анехогенних утворень з нечіткими контурами в проекції сальникової сумки. В подальшому у хворих прогресували явища деструктивного панкреатиту. У випадках розвитку неінфільтративного панкреонекрозу у пацієнтів спостерігали картину псевдокист підшлункової залози.

4. Ізольовані ушкодження селезінки спостерігалися у 31\%, в 69\% травма селезінки була сукупною з ушкодженнями інших органів черевної порожнини. Виявлено, що при ультразвуковому дослідженні селезінки головними ознаками її ушкоджень $€$ неоднорідність паренхіми та наявність анехогенної структури і вільної рідини в черевній порожнині. В 69\% випадків виявили нечіткість та нерівність контурів селезінки, а також збільшення її розмірів. Виявлена наступна динаміка змін: в першу добу має місце неоднорідна гіпоехогенна внутрішня структура гематом; наявність гіпоехогенних включень в паренхімі селезінки; в подальшому ультразвукова картина гематом ставала відносно стабільною, контури гематом більш чіткі, гематоми збільшувались у розмірах, їх внутрішня ехогенна структура могла бути як однорідною, так і неоднорідною; після 7 доби, з моменту травми, гематоми у розмірах не збільшувались. 
5. Ізольовані ушкодження нирок спостерігаються практично у 15\% травмованих осіб, в 85\% випадків ушкодження нирок виявляються у поєднанні 3 травмами інших паренхіматозних органів. Характерними ознаками гематоми нирок є: збільшення їх розмірів, неоднорідність структури з підвищенням ехогенності паренхіми, розмитістю контурів та їх переривчастістю. Протягом першої доби, після травмування, гематоми нирок характеризувалися наявністю ділянок підвищеної ехогенності з розмитими, нерівними контурами та, в подальшому, гематоми візуалізувалися як гіпоехогенні включення в паренхіми нирок з неоднорідною структурою, контури їх ставали більш чіткими та впродовж 3-4 діб гематоми набували максимальних розмірів. Починаючи з 7 доби гематоми нирок не збільшувались в розмірах, контури їх були чіткі, рівні, гіпоехогенність зменшувалась та, в подальшому, ушкоджені тканини відновлювались.

Перспективи подальших досліджень. Подальше проведення досліджень, присвячених вивченню особливостей ушкоджень печінки, підшлункової залози, селезінки, нирок, зокрема діагностики механізму, характеру та давності виникнення травми, необхідне для розробки і застосування профрілактичних заходів травматизму.

\section{References}

1. Smolyar AN, Dzhagraev KR. Odnoetapnoe khirurgicheskoe lechenie tyazheloy zakrytoy sochetannoy travmy pecheni [One-stage surgical treatment of severe closed combined liver trauma surgery]. Surgery. Pirogov Journal. 2015; (2): 79-81. [Russian]. PMID: 26031825. doi: 10.17116/hirurgia2015279-81

2. Sigua BV, Zemlyanoi VP, Dykov AK. Zakrytaya travma zhivota s povrezhdeniem pecheni [Blunt abdomen trauma liver damage]. Bulletin of Mechnikov North-West State Medical University. 2014; 6(3): 93-98. [Russian]

3. Timerbulatov VM, Fayazov RR, Timerbulatov ShV, Gareev RN, Nguyen KhK, Khalikov AA, et al. Khirurgicheskaya taktika pri travmaticheskikh povrezhdeniyakh pecheni $s$ pozitsiy sovremennykh tekhnologiy (klinikoeksperimentalnoe issledovanie) [Surgical tactics for traumatic liver damage from the standpoint of modern technologies (clinical and experimental research)]. Medical Bulletin of Bashkortostan. 2012; 7(6): 64-69. [Russian]

4. Bazaev AV, Aleynikov AV, Korolev SK, Kokobelyan AR, Rodin AG, Efremenko VA, et al. Povrezhdeniya pecheni i selezyonki u postradavshikh s sochetannoy avtodorozhnoy travmoy [Damage to the liver and spleen in patients with combined road injury]. Selected issues of treatment of trauma to the chest and abdomen. 2014; 1(11): 1719. [Russian]

5. Parkhisenko YuA, Vorontsov AK, Vorontsov KE, Bezaltynnykh AA. Analiz rezultatov khirurgicheskogo lecheniya patsientov $s$ travmaticheskimi povrezhdeniyami pecheni [Analysis of the results of surgical treatment of patients with trauma of the liver]. Prospects for Science and Education. 2018; 1(31): 245-250. [Russian]

6. Samokhvalov IM, Afonchikov VS, Badalov VI, Borisov MB. Prakticheskoe rukovodstvo po Damage Control [Practical Guide to Damage Control]. SPb: R-COPI; 2018. 370 p. [Russian]

7. Afifi I, Abayazeed S, El-Menyar A, Abdelrahman H, Peralta R, Al-Thani H. Blunt liver trauma: a descriptive analysis from a level I trauma center. BMC Surg. 2018; 18(1): 42. PMID: 29914487. PMCID: PMC6006727. doi: 10.1186/s12893-018-0369-4

8. Badger SA, Barclay R, Campbell P, Mole DJ, Diamond T. Management of liver trauma. World J Surg. 2009 Dec; 33(12): 2522-37. PMID: 19760312. doi: 10.1007/s00268-009-0215-z

9. Boese CK, Hackl M, Müller LP, Ruchholtz S, Frink M, Lechler P. Nonoperative management of blunt hepatic trauma: a systematic review. J Trauma Acute Care Surg. 2015; 79(4): 654-60. PMID: 26402542. doi: 10.1097/ TA.0000000000000814

10. Biffl WL, Leppaniemi A. Management guidelines for penetrating abdominal trauma. World J Surg. 2015; 39(6): 1373-80. PMID: 25315088. doi: 10.1007/s00268-014-2793-7

11. Briggs A, Askari R. Damage control resuscitation. Int J Surg. 2016 Sep; 33(Pt B): 218-221. PMID: 27107662. doi: 10.1016/j.ijsu.2016.03.064

12. Brillantino A, lacobellis F, Festa P, Mottola A, Acampora C, Corvino F, et al. Non-operative management of blunt liver trauma: safety, efficacy and complications of a standardized treatment protocol. Bull Emerg trauma. 2019; 7(1): 49-54. PMID: 30719466. PMCID: PMC6360015. doi: 10.29252/beat-070107

13. Buci S, Torba M, Gjata A, Kajo I, Bushi G, Kagjini K. The rate of success of the conservative management of liver trauma in a developing country. World J Emerg Surg. 2017; 12: 24. PMID: 28596799. PMCID: PMC5463417. doi: 10.1186/s13017-017-0135-4

14. Catalano O, Lobianco R, Raso MM, Siani A: Blunt hepatic trauma: evaluation with contrast-enhanced sonography. J Ultrasound Med. 2005, 24: 299-310. PMID: 15723842. doi: 10.7863/jum.2005.24.3.299

15. Coccolini F, Montori G, Catena F, Di Saverio S, Biffl W, Moore EE, et al. Liver trauma: WSES position paper. World J Emerg Surg. 2015; 10: 39. PMID: 26309445. PMCID: PMC4548919. doi: 10.1186/s13017-015-0030-9 
16. Cokkinos D, Antypa K, Stefanidis K, et al. Contrast-Enhanced Ultrasound for imaging blunt abdominal trauma - Indication, description of the technique and imaging review. Ultraschall in Med. 2012, 33: 60-67. PMID: 22274907. doi: 10.1055/s-0031-1273442

17. Cothren CC, Moore EE. Hepatic Trauma. Eur J Trauma Emerg Surg. 2008 Aug; 34(4): 339-54. PMID: 26815811. doi: 10.1007/s00068-008-8029-5

18. Fodor M, Primavesi F, Morell-Hofert D, Haselbacher M, Braunwarth E, Cardini B, et al. Non-operative management of blunt hepatic and splenic injuries-practical aspects and value of radiological scoring systems. Eur Surg. 2018; 50(6): 285-98. PMID: 30546386. PMCID: PMC6267420. doi: 10.1007/s10353-018-0545-x

19. Hommes M, Navsaria PH, Schipper IB, Krige JEJ, Kahn D, Nicol AJ. Management of blunt liver trauma in 134 severely injured patients. Injury. 2015; 46(5): 837-42. PMID: 25496854. doi: 10.1016/j.injury.2014.11.019

20. Jiang H, Wang J. Emergency strategies and trends in the management of liver trauma. Front Med. 2012; 6(3): 225-233. PMID: 22673827. doi: 10.1007/s11684-012-0186-6

21. Hsu JM, Joseph AP, Tarlinton LJ, Macken L, Blome S. The accuracy of focused assessment with sonography in trauma (FAST) in blunt trauma patients: experience of an Australian major trauma service. Injury. 2007 Jan; 38(1): 71-5. PMID: 16769069. doi: 10.1016/j.injury.2006.03.004

22. Kozar RA, Crandall M, Shanmuganathan K, Zarzaur BL, Coburn M, Cribari C, et al. AAST Patient Assessment Committee. Organ injury scaling 2018 update: Spleen, liver, and kidney. J Trauma Acute Care Surg. 2018 Dec; 85(6): 1119-1122. PMID: 30462622. doi: 10.1097/TA.0000000000002058

23. Mazur R, Celmer M, Silicki J. Clinical applications of spleen ultrasound elastography - a review. J Ultrason. 2018; 18(72): 37-41. PMID: 29844939. PMCID: PMC5911717. doi: 10.15557/JoU.2018.0006

24. Launey Y, Fryer TD, Hong YT, Steiner LA, Nortje J, Veenith TV, et al. Spatial and temporal pattern of ischemia and abnormal vascular function following traumatic brain injury. JAMA Neurol. 2020 Mar 1; 77(3): 339-349. PMID: 31710336. PMCID: PMC6865302. doi: 10.1001/jamaneurol.2019.3854

25. Lin BC, Fang JF, Chen RJ, Wong YC, Hsu YP. Surgical management and outcome of blunt major liver injuries: experience of damage control laparotomy with perihepatic packing in one trauma centre. Injury. 2014 Jan; $45(1)$ : 122-7. PMID: 24054002. doi: 10.1016/j.injury.2013.08.022

26. Cagini L, Gravante S, Malaspina CM, Cesarano E, Giganti M, Rebonato A, et al. Contrast enhanced ultrasound (CEUS) in blunt abdominal trauma. Critical Ultrasound J. 2013; 5: S9. PMID: 23902930. PMCID: PMC3711741. doi: 10.1186/2036-7902-5-S1-S9

27. Navsaria P, Nicol A, Krige J, Edu S, Chowdhury S. Selective nonoperative management of liver gunshot injuries. Eur J Trauma Emerg Surg. 2019; 45(2): 323-8. PMID: 29368085. doi: 10.1007/s00068-018-0913-z

28. Omar A, Freeman S. Contrast-enhanced ultrasound of the spleen. Ultrasound. 2016; 24(1): 41-49. PMID: 27433274. PMCID: PMC4760613. doi: 10.1177/1742271X15617214

29. Parrado R, Notrica DM, Garcia NM, Alder AC, Eubanks JW, Maxson RT, et al. Use of laparoscopy in pediatric blunt and spleen injury: an unexpectedly common procedure after cessation of bleeding. J Laparoendosc Adv Surg Tech A. 2019; 29(10): 1281-4. PMID: 31397620. doi: 10.1089/lap.2019.0160

30. Rauchfuss F, Voigt R, Götz M, Heise M, Uberrück T, Settmacher U. Damage control concept in liver trauma. Package strategies and secondary measures. Chirurg. 2009; 80(10): 923-928. PMID: 19727579. doi: 10.1007/ s00104-009-1728-6

31. Rodríguez Vargas D, Parada Blázquez M, Vargas Serrano B. Diagnostic imaging of abnormalities in the location of the spleen and in the number of spleens. Radiologia. 2019 Jan-Feb; 61(1): 26-34. doi: 10.1016/j. rx.2018.07.002

32. Salcedo Joven I, Segura-Grau A, Díaz Rodríguez N, Segura-Cabral J. Ultrasound of spleen and retroperitoneum. Semergen. 2016; 42(6): 395-401. PMID: 25891487. doi: 10.1016/j.semerg.2015.02.007

33. Setoublon C, Amariutei A, Taton N, Lacaze L, Abba J, Risse O, et al. Management of blunt hepatic trauma. $J$ Visc Surg. 2016; 153(4 Suppl): 33-43. PMID: 27519150. doi: 10.1016/j.jviscsurg.2016.07.005

34. Soto JA, e Anderson SW: Multidetector CT of blunt abdominal trauma. Radiology. 2012, 265: 678-693. PMID: 23175542. doi: 10.1148/radiol.12120354

35. Stassen NA, Bhullar I, Cheng JD, Crandall M, Friese R, Guillamondegui O, et al. Eastern Association for the Surgery of Trauma. Nonoperative management of blunt hepatic injury: an Eastern Association for the Surgery of Trauma practice management guideline. J Trauma Acute Care Surg. 2012 Nov; 73(Suppl 4): S288-93. PMID: 23114483. doi: 10.1097/TA.0b013e318270160d

36. Swendiman RA, Goldshore MA, Fenton SJ, Nance ML. Defining the role of angioembolization in pediatric isolated blunt solid organ injury. J Pediatr Surg. 2020 Apr; 55(4): 688-692. doi: 10.1016/j.jpedsurg.2019.04.036

37. Tignanelli CJ, Joseph B, Jakubus JL, Iskander GA, Napolitano LM, Hemmila MR. Variability in management of blunt liver trauma and contribution of level of American College of Surgeons Committee on Trauma verification status on mortality. J Trauma Acute Care Surg. 2018; 84(2): 273-9. PMID: 29194321. doi: 10.1097/ TA.0000000000001743 
38. Zarzaur BL, Kozar RA, Fabian TC, Coimbra R. A survey of American Association for the Surgery of Trauma member practices in the management of blunt splenic injury. J Trauma. 2011; 70(5): 1026-31. PMID: 21610420. doi: 10.1097/TA.0b013e318217080c

39. Valentino M, Serra C, Pavlica P, Barozzi L. Contrast-Enhanced Ultrasound for blunt abdominal trauma. Semin Ultrasound CT MR. 2007; 28(2): 130-140. PMID: 17432767. doi: 10.1053/j.sult.2007.01.008

40. Vancauwenberghe T, Snoeckx A, Vanbeckevoort D, Dymarkowski S, Vanhoenacker FM. Imaging of the spleen: what the clinician needs to know. Singapore Med J. 2015; 56(3): 133-144. PMID: 25820845. PMCID: PMC4371192. doi: 10.11622/smedj.2015040

\section{УДК 360.6:616.441-001-076}

\section{УЛЬТРАЗВУКОВАЯ ДИАГНОСТИКА ХАРАКТЕРА И ДАВНОСТИ ТРАВМЫ ЖИВОТА}

\section{Бабкина Е. П., Данильченко С.И.}

Резюме. Целью данной работы было изучение комплекса изменений ультразвуковых показателей травмированных тканей печени, селезенки, поджелудочной железы при механической травме, и их зависимость от характера и давности травмы.

Материал и методы исследования. Были проведены ультразвуковые исследования у 60 травмированных пациентов (41 мужского и 19 женского пола) в возрасте от 20 до 60 лет в динамике на 1, 2, 3, 4 и 5 сутки после получения травмы. Применяли продольное, поперечное и косое сканирование из всех возможных доступов согласно протокола ультразвукового сканирования органов брюшной полости и забрюшинного пространства последовательно в В-режиме. Исследовали состояние печени, поджелудочной железы, селезенки, почек.

Результаты. В ходе проведенных исследований продемонстрирована высокая количество повреждений органов брюшной полости и забрюшинного пространства, доказано, что изолированные повреждения печени наблюдались $32 \%$, в 68\% травма печени была совокупной с повреждениями других органов брюшной полости. Изолированные повреждения поджелудочной железы наблюдали в 10\%, в остальных 90\% травма поджелудочной железы была совокупной с повреждениями печени, желчного пузыря и внепеченочных желчных протоков, селезенки, кишечника. Изолированные повреждения селезенки наблюдались у пациентов в $31 \%$, в других случаях травма селезенки была совокупной с повреждениями других органов брюшной полости. Изолированные повреждения почек мы наблюдали практически 15\%. В 85\% случаях повреждения почек наблюдались в сочетании с травмами других паренхиматозных органов. Продемонстрировано, что в области травмированных тканей печени, поджелудочной железы, селезенки, почек при тупой травме живота у лиц с отсутствием признаков алкогольной интоксикации наблюдаются закономерные ультразвуковые изменения, которые находятся в прямой зависимости от времени, прошедшего с момента причинения повреждений.

Выводы. Для определения времени причинения повреждений использования в комплексе изменений в паренхиматозных органах, выявленных при ультразвуковых исследованиях, как в случаях изолированной травмы органа, так и в случаях сочетанной травмы органов брюшной полости и забрюшинного пространства, целесообразно, так как позволяет повысить об объективность результатов установления давности причинения травмы.

Ключевые слова: ультразвуковые исследования, диагностика, тупая травма, печень, селезенка, поджелудочная железа, почки, давность повреждения.

\section{UDC 360.6:616.441-001-076}

\section{Ultrasound Diagnostics of the Nature and Duration of Abdominal Trauma \\ Babkina O. P., Danylchenko S. I.}

Abstract. The purpose of the study was to study a complex of changes in ultrasound parameters of injured tissues of the liver, spleen, pancreas in mechanical trauma and their dependence on the nature and duration of injury.

Materials and methods. Ultrasound examinations were performed in 60 injured patients (41 males and 19 females) aged 20 to 60 years old in the dynamics as for the $1^{\text {st }}, 2^{\text {nd }}, 3^{\text {rd }}, 4^{\text {th }}$ and $5^{\text {th }}$ days after injury. Puncture, transverse and oblique scans from all possible accesses were used. The conditions of the liver, pancreas, spleen, kidneys were studied.

Results and discussion. In the course of the studies, a high number of injuries to the abdominal and retroperitoneal organs was demonstrated; it was proved that isolated liver injuries were observed in $32 \%$, in $68 \%$ the liver injury was combined with injuries of other abdominal organs. We observed isolated damage to the pancreas in $10 \%$, in the remaining $90 \%$, the injury to the pancreas was combined with damage to the liver, gallbladder and extrahepatic bile ducts, spleen, and intestines. Isolated injuries of the spleen were observed 
in $31 \%$ of patients; in other cases, the injury to the spleen was combined with injuries of other organs of the abdominal cavity. We observed isolated kidney damage in almost $15 \%$. In $85 \%$ of cases, kidney damage was observed in combination with injuries of other parenchymal organs. It has been demonstrated that in the area of injured tissues of the liver, pancreas, spleen, and kidneys with blunt trauma to the abdomen in persons with no signs of alcohol intoxication, regular ultrasound changes are observed, which are in direct proportion to the time elapsed since the injury was caused. The main ultrasound signs of liver damage were ruptures of the parenchyma with the formation of intra-parenchymal or subcapsular hematomas. In general, for almost all the injured people the following sings were characteristic as an increase in liver size (often due to increased part of damage), heterogeneity of structure, blurred contours and their discontinuity, presence of hypo- and anechoic areas (hematomas) on the background of intact parenchyma. Characteristic ultrasound criteria of pancreatic damage in the first day are the lack of clear contours of the gland, their discontinuity, increase in the size of the gland, the presence of hypoechoic areas of different sizes. At ultrasound examination of the spleen, the main signs of its damage are the heterogeneity of the parenchyma and the presence of anechoic structure and free fluid in the abdominal cavity. In $69 \%$ of cases, the main sings were blurred and uneven contours of the spleen, as well as an increase in its size. Characteristic features of renal hematoma are an increase in their size, heterogeneity of structure with increasing echogenicity of the parenchyma, blurred contours and their discontinuity.

Conclusion. It has been proven that it is advisable to use in a complex of changes in the parenchymal organs revealed by ultrasound examinations, both in cases of isolated organ trauma, and in cases of combined trauma of the abdominal cavity and retroperitoneal organs, to determine the time of causing damage, since it makes it possible to increase the objectivity of the results of establishing the duration of the injury.

Keywords: ultrasound examinations, diagnostics, blunt trauma, liver, spleen, pancreas, kidneys, duration of damage.

The authors of this study confirm that the research and publication of the results were not associated with any conflicts regarding commercial or financial relations, relations with organizations and/or individuals who may have been related to the study, and interrelations of coauthors of the article. 